\title{
Hyperthermia increases the metastatic potential of murine melanoma
}

R.S. Oliveira-Filho', R.G. Bevilacqua ${ }^{1}$ and R. Chammas ${ }^{2}$

\author{
1Departamento de Cirurgia Abdominal, Hospital A.C. Camargo, \\ Fundação Antonio Prudente, 01509-010 São Paulo, SP, Brasil \\ ${ }^{2}$ Instituto Ludwig de Pesquisa sobre o Câncer, 01509-010 São Paulo, SP, Brasil
}

\footnotetext{
Correspondence

R.S. Oliveira-Filho

Rua Carlos Milan, 37

01456-030 São Paulo, SP

Brasil

Fax: 55 (011) 242-5088
}

Research supported by FAPESP.

.....................

Received August 30, 1996

Accepted June 30, 1997

\begin{abstract}
Hyperthermia, either alone or combined with radio-, immuno- or chemotherapy, can control tumor growth, but its effect on metastasis is still controversial. In the present study, we investigated the influence of hyperthermia on the metastatic potential of B16-F10 murine melanoma cells. Incubation of melanoma cells at $43^{\circ} \mathrm{C}$ for $30 \mathrm{~min}$ led to a significant decrease in cell viability. About half of the cells survived the acute exposure to heat. These thermoresistant cells displayed a longer lag phase as compared to control unheated B16-F10 melanoma cells. Other parameters of cell growth such as doubling time and saturation density were equivalent in both control and thermoresistant cells. Both control and treated cells were adherent, but thermoresistant cells failed to spread during the first $48 \mathrm{~h}$ after heat exposure. B16-F10 cells colonize the lungs of C57BL/6J mice when injected intravenously; the number of lung colonies is a measure of the metastatic potential of injected cells. Median values of 22, 10.5 and 31 colonies per injected mouse were observed for control cells, cells heated to $43^{\circ} \mathrm{C}$ for $30 \mathrm{~min}$ and thermoresistant cells, respectively, with statistically significant differences between groups (Mann-Whitney test, $\mathrm{P}<0.02)$. Thus, despite its cytotoxic action, heat exposure induced the acquisition of a more metastatic phenotype in a subpopulation of B16-F10 cells.
\end{abstract}

Key words

- Induced hyperthermia

- B16-F10 melanoma

- Lung metastasis
More than two thirds of cancer deaths are caused by metastases resistant to treatment which may be present, but undetectable, even in the early stages of the disease. As the tumor progresses, neoplastic cells are amenable to changes which generate a heterogeneous cell population. Tumor cell heterogeneity represents a further complication in planning adequate treatment for metastatic disease. For most cases, no effective treatment is available, and frequently different therapeutic modalities are combined in the management of cancer patients.

Hyperthermia has been reported to be beneficial for the treatment of cancer since ancient Greece. Hippocrates stated that fire would be successful when all other methods failed (1). However, only in 1985 did the United States Food and Drug Administration recognize hyperthermia as an effective treatment for some cancers $(2,3)$. Hyperthermia is now accepted as a therapeutic modality for cancer palliation. There is good evidence that hyperthermia alone or in combination with radio-, immuno- or chemotherapy can control the local growth of tumors. Currently, hyperthermia is indicated in combination with radiotherapy for the treatment of 
skin tumors $(4,5)$ and in combination with the antiblastic agent melphalan for the treatment of malignant melanoma of the extremities $(1,6,7)$. In experimental models, combination of hyperthermia and cytokines, e.g. interleukin-2, suppressed tumor growth (8). However, the long-term effects of hyperthermia, such as its effects on metastatic potential, are still controversial $(4,9)$.

In this study, we investigated the effects of hyperthermia on the growth parameters and metastatic potential of a murine melanoma cell line, B16-F10. This model was first established by Fidler (10) from a spontaneous melanoma tumor of $\mathrm{C} 57 \mathrm{BL} / 6 \mathrm{~J}$ mice. By means of progressive selection, Fidler isolated variants with different metastatic potentials. B16-F10 is one of these variant cell lines, suitable for experimental metastasis assays. Once injected into the tail vein, B16-F10 cells colonize lungs within 2-3 weeks. Since these cells produce melanin, dark (brown/black) lung nodules are easily counted with the aid of a magnifying glass.

B16-F10 cells were cultured in RPMI 1640 (Sigma, St. Louis, MO) supplemented with $10 \%$ heat-inactivated fetal calf serum (Cultilab, Campinas, Brazil) and $50 \mathrm{mg} / \mathrm{ml}$ gentamicin sulfate in a humidified incubator equilibrated with $5 \% \mathrm{CO}_{2}$ at $37^{\circ} \mathrm{C}$. All reagents used were purchased from Sigma (St. Louis, MO). Cells were harvested at subconfluence with PBS-EDTA $(10 \mathrm{mM}$ sodium phosphate buffer, $150 \mathrm{mM} \mathrm{NaCl}$, and $2 \mathrm{mM}$ EDTA, pH 7.4). The cells used in this study were not maintained for more than 15 consecutive passages in culture.

We first evaluated the effects of temperature on cell viability. In a first set of experiments, B16-F10 cells were heated to 37, 43 and $46^{\circ} \mathrm{C}$ for $30 \mathrm{~min}$ in PBS-EDTA. Cell viability was then determined using Trypan blue dye exclusion (11). Viable cell membranes are not permeable to the dye, while dead cells readily stain blue. The percentage of viable cells in each experimental condition was then determined by light micros- copy. While in the control group (cells heated to $37^{\circ} \mathrm{C}$ in PBS-EDTA), $81.4 \%$ of cells remained alive after 30 min (median value), $63.2 \%$ of cells heated to $43^{\circ} \mathrm{C}$ and $38.4 \%$ of cells heated to $46^{\circ} \mathrm{C}$ were viable after 30 min. Nine samples from each group were counted and the groups were compared by the Kruskal-Wallis test. Differences in the median values were statistically significant $(\mathrm{P}<0.05)$. These results indicate that PBSEDTA alone leads to cell death if used for a prolonged period of time. The additional effect of exposure to increased temperatures was also clearly demonstrated. Thermosensitivity varies within different cell types and even within variants of the same cell line. B16-F1, a less invasive variant of the B16 cell line, is more resistant to temperature exposure than B16-F10 (12). In vitro, normal cells are more resistant to hyperthermia than neoplastic cells $(13,14)$. This is equivalent to saying that the thermal dose required to induce cell death is higher for normal cells as compared to their malignant counterparts.

The thermal dose is related not only to temperature of exposure, but also to duration of exposure (14). We next compared the exposure of B16-F10 cells to $37^{\circ} \mathrm{C}$ and $43^{\circ} \mathrm{C}$ for increasing periods of time (15 to $75 \mathrm{~min}$ ). Cell viability was determined as described above. As expected, cell viability decreased gradually with time in both groups. After 75 min, cell viability was about $75.9 \%$ (median value of 6 samples) in the control group, while in the group heated to $43^{\circ} \mathrm{C}$ only $30.5 \%$ of the cells were viable (median value of 6 samples) ( $\mathrm{P}<0.05$, Kruskal-Wallis test). As mentioned above, approximately $60 \%$ of cells died after a $30-\mathrm{min}$ exposure to $46^{\circ} \mathrm{C}$. Exposure for $60-75 \mathrm{~min}$ to $43^{\circ} \mathrm{C}$ caused a similar effect.

In these experiments, we evaluated cell death using a rather insensitive method. Loss of cell membrane permeability is a late event in the biochemistry of cell death (11). Thus, in these assays the cytotoxic effects of hyperthermia are clearly underestimated. To 
circumvent this limitation, we studied cell behavior after heat exposure and observed a progressive decrease in cell viability for up to $3 \mathrm{~h}$ after cessation of hyperthermia (data not shown). However, a number of cells (about 44\%) were resistant to exposure to $43^{\circ} \mathrm{C}$ for $30 \mathrm{~min}$ (thermoresistant).

B16-F10 cells are highly adherent and spread, presenting neurite-like cytoplasmic extensions (Figure 1a and c; Reference 15). Thermoresistant B16-F10 cells were adherent, but did not spread completely within the first $48 \mathrm{~h}$ after heat exposure (Figure $1 \mathrm{~b}$ and d). Cell growth was also monitored and the lag phase of thermoresistant cells was found to be longer than that of control cells. Once the log phase was achieved, both control and thermoresistant B16-F10 cells displayed similar doubling times and reached the same saturation density (data not shown). Thus, the growth parameters of thermoresistant cells did not vary significantly.

In order to evaluate the effect of hyperthermia on the metastatic potential of B16F10 cells, three experimental groups were defined: a) control, cells heated to $37^{\circ} \mathrm{C}$ for 30 min in PBS-EDTA (group $37^{\circ} \mathrm{C}$ ); b) cells heated to $43^{\circ} \mathrm{C}$ for $30 \mathrm{~min}$ in PBS-EDTA (group $43^{\circ} \mathrm{C}$ ), and c) cells heated to $43^{\circ} \mathrm{C}$ for $30 \mathrm{~min}$ in PBS-EDTA and then maintained in tissue culture for 13 days (group $43^{\circ} \mathrm{C}$ d13). Sets of $30 \mathrm{C} 57 \mathrm{BL} / 6 \mathrm{~J}$ female mice, aged 4-6 weeks, were divided into three groups. Animals were injected intravenously into the lateral tail vein with $10^{5}$ viable cells of one of the groups described above. Three independent sets of 30 animals each were injected. Errors of intravenous injections occurred in some animals in all three groups, and in these cases the cells were injected into the subcutaneous tissues of the tail. Tail tumors were then observed, but the data for these animals were not included in the analysis. In the three sets, 29, 28 and 27 animals were injected with cells from groups $37^{\circ} \mathrm{C}$, $43^{\circ} \mathrm{C}$ and $43^{\circ} \mathrm{C}-\mathrm{d} 13$, respectively. After 3 weeks, the animals were sacrificed under anesthesia and exsanguinated, and the lungs were excised and fixed in $3.7 \%$ formaldehyde. After fixation, pigmented lung nodules were counted and the results are shown in Figure 2. The median numbers of metastatic nodules in groups $37^{\circ} \mathrm{C}, 43^{\circ} \mathrm{C}, 43^{\circ} \mathrm{C}$ d13 were 22, 10.5 and 31 , respectively.

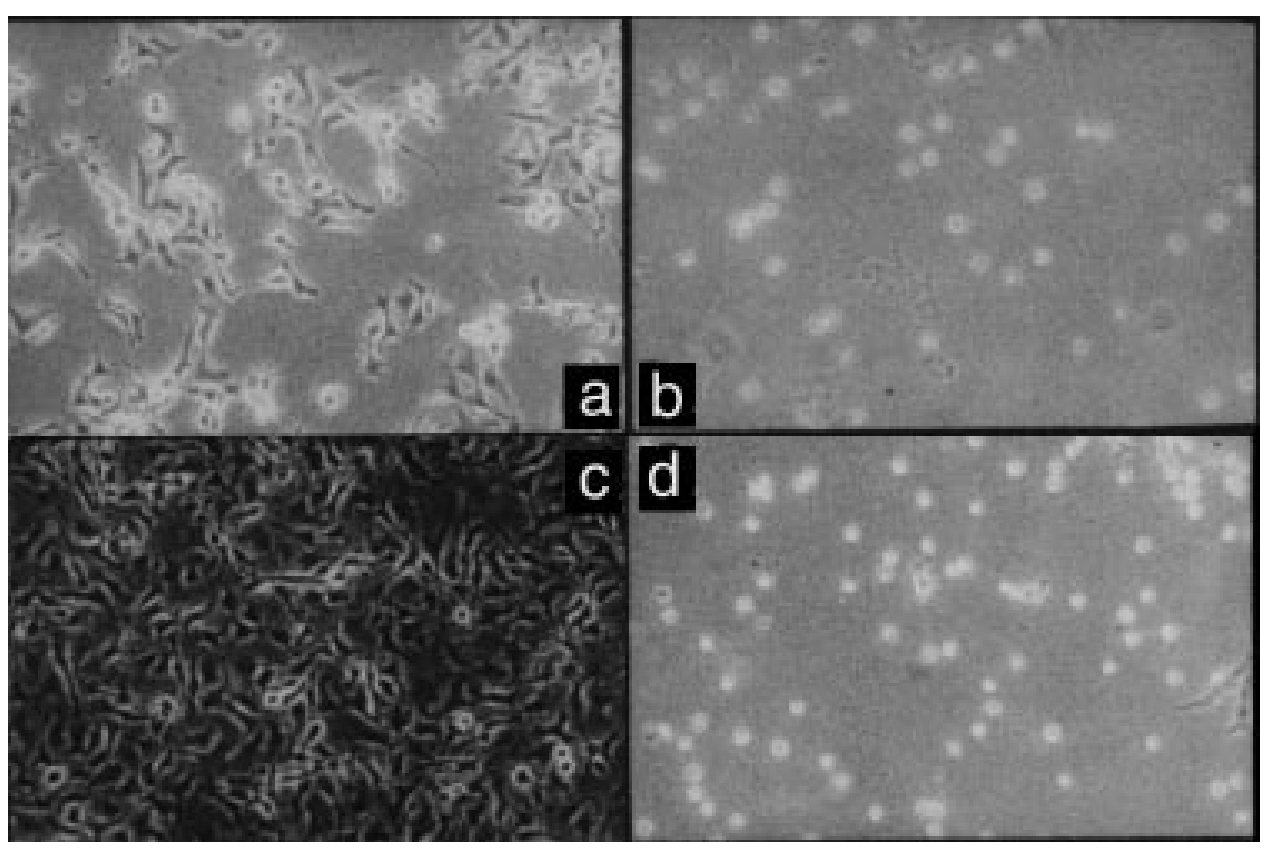

Figure 1 - Spreading, but not adhesion, of B16-F10 cells is delayed after acute heat exposure. Suspensions of B16-F10 cells were exposed to $37^{\circ} \mathrm{C}$ (a and $\mathrm{C}$ ) or $43^{\circ} \mathrm{C}(\mathrm{b}$ and $\mathrm{d})$ for $30 \mathrm{~min}$ Control and heated cells were then cultured. After $24 \mathrm{~h}$ (a and b), control cells adhered and spread while heated cells (thermoresistant) adhered but did not spread. After $48 \mathrm{~h}$ (c and d), some thermoresistant cells displayed the cytoplasmic projections typical of cell spreading (d). 
Figure 2 - Metastatic potential of control $\left(37^{\circ} \mathrm{C}\right)$, acutely injected heated cells $\left(43^{\circ} \mathrm{C}\right)$ and thermoresistant $\left(43^{\circ} \mathrm{C}-\mathrm{d} 13\right)$ B16-F10 cells. Control and treated cells were injected intravenously into C57BL/6J mice $\left(10^{5}\right.$ cells/ mouse). After 21 days, the animals were sacrificed and the number of lung colonies was counted. Groups $37^{\circ} \mathrm{C}, 43^{\circ} \mathrm{C}$, and $43^{\circ} \mathrm{C}-\mathrm{d} 13$ consisted of 29 , 28 and 27 animals, respectively. Pairwise comparison $\left(37^{\circ} \mathrm{C}\right.$ vs $43^{\circ} \mathrm{C}, 37^{\circ} \mathrm{C}$ vs $43^{\circ} \mathrm{C}-\mathrm{d} 13,43^{\circ} \mathrm{C}$ vs $\left.43^{\circ} \mathrm{C}-\mathrm{d} 13\right)$ demonstrated a significant difference in the metastatic potential of $43^{\circ} \mathrm{C}$ heated cells (decrease as compared to control) and of thermoresistant cells (increase as compared to control) ( ${ }^{*} \mathrm{P}<0.02$, Mann-Whitney test).

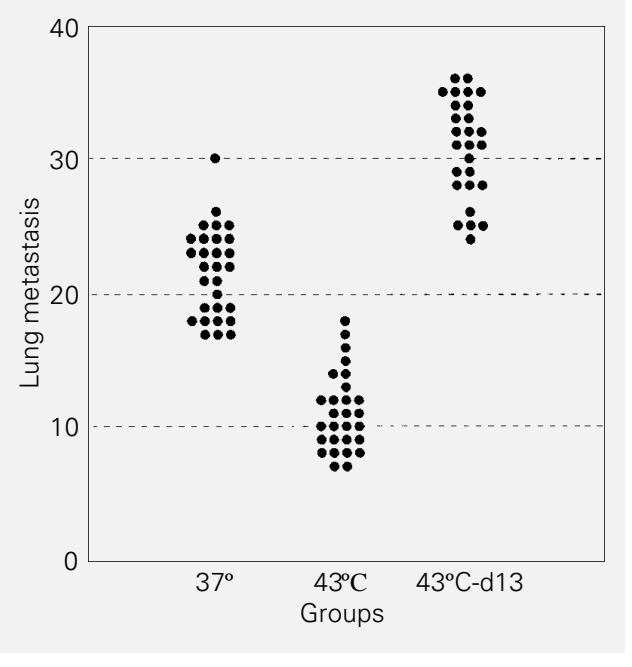

Pairwise comparisons $\left(37^{\circ} \mathrm{C}\right.$ vs $43^{\circ} \mathrm{C} ; 37^{\circ} \mathrm{C}$ vs $43^{\circ} \mathrm{C}-\mathrm{d} 13 ; 43^{\circ} \mathrm{C}$ vs $\left.43^{\circ} \mathrm{C}-\mathrm{d} 13\right)$ indicated that differences were statistically significant (Mann-Whitney test, $\mathrm{P}<0.02$ ).

The decrease in number of metastatic nodules observed in the $43^{\circ} \mathrm{C}$ group as compared to the $37^{\circ} \mathrm{C}$ group should be understood as a consequence of the cytotoxic effect of hyperthermia. Although the number of viable cells injected was the same, as mentioned above, cell viability decreased at a higher rate in the $43^{\circ} \mathrm{C}$ group than in the $37^{\circ} \mathrm{C}$ group even after the cessation of hyperthermia. On the other hand, group $43^{\circ} \mathrm{C}$ - d13 showed a significant increase in the number of metastatic foci as compared to the control group. This difference in metastatic potential may be due to some selective effect of heating stress, either directly or indirectly involved in the propagation of more invasive B16-F10 subclones. Similar results were reported for local hyperthermia in melanomabearing mice (16).

The phenotypic changes that determined the increased metastatic behavior, as well as the differences in cell spreading of thermoresistant B16-F10 subclones, are still unknown. This experimental model may provide a useful system for determining the molecular mechanisms in the later steps of the metastatic cascade (arrest in the vasculature and extravasation) (17). Furthermore, the fact that more aggressive cell populations may be generated with stressful stimuli such as heating may serve as a cautionary note for those interested in using hyperthermia as a therapeutic modality for humans.

\section{Acknowledgments}

We thank Maria Carolina Q.B. Elias for helpful assistance and Prof. R.R. Brentani for continuous support. 


\section{References}

1. Storm FK (1986). Background, principles and practice. In: Storm FK (Editor), Hyperthermia in Cancer Therapy. GK Hall Medical Publishers, Boston, 1-8.

2. Carper SWW, Duffy JJ \& Gerner EW (1987). Heat shock proteins in thermotolerance and other cellular processes. Cancer Research, 47: 5249-5255.

3. Oliveira-Filho RS, Silva DCP, Bevilacqua RG \& Birolini D (1993). Perfusão antiblástica hipertérmica regional no melanoma de membros em adultos. Revista do Colégio Brasileiro de Cirurgiões, 20: 137147.

4. Oleson JR (1993). Hyperthermia. In: De Vitta Jr VT, Hellman S \& Rosenberg SA (Editors), Cancer Principles \& Practice of Oncology. JB Lippincott, Philadelphia, 2725-2733.

5. Eugin K, Leeper DB, Tupchong L, Waterman FM \& Mansfield CM (1993). Thermoradiation therapy for superficial malignant tumors. Cancer, 72: 287-296.

6. Stehlin Jr JS, Giovanella BC, De Ipolyi PD, Muenz LR \& Anderson RF (1975). Results of hyperthermic perfusion for melanoma of the extremities. Surgery, Gynecology and Obstetrics, 140: 339-348.
7. Engelhardt R (1987). Hyperthermia and drugs. Recent Results in Cancer Research, 104: 136-203.

8. Geehan DM, Fabian DF \& Lefor AT (1995). Combined local hyperthermia and immunotherapy treatment of an experimental subcutaneous murine melanoma. Journal of Surgical Oncology, 59: 35-39.

9. Nathanson SD, Cerra RF, Helzel FW, Zarbo RJ, Crissman JD, Page R, Anaya P \& Westrick $P$ (1984). Thermal dose expression in clinical hyperthermia and correlation with tumor response control. Cancer Research, 44: 4818s-4825s.

10. Fidler IJ (1973). Selection of successive tumor lines for metastasis. Nature, 242: 148-149.

11. McGahon AJ, Martin SJ, Bissonnette RP, Mahboubi A, Shi Y, Mogil RJ, Nishioka WK \& Green DR (1995). The end of the cell (line): methods for the study of apoptosis in vitro. In: Schwartz LM \& Osborne BA (Editors), Cell Death. Academic Press, San Diego, 153-185.

12. Leibovici J, Klorin G, Huszr M, Hoenig S \& Michowitz M (1991). Differential sensitivity to hyperthermia of the F1 and F10 B16 melanoma variants. International Journal of Experimental Pathology, 72: 139-150.
13. Giovanella BC, Stehlin Jr JS \& Morgan AC (1976). Selective lethal effect of supranormal temperature on human neoplastic cells. Cancer Research, 36: 3944-3950.

14. Overgaard J \& Suit HD (1979). Time-temperature relationship in hyperthermic treatment of malignant and normal tissue in vivo. Cancer Research, 39: 3248-3253.

15. Chammas R, Veiga SS, Travassos LR \& Brentani R (1993). Functionally distinct roles for glycosylation of $\alpha$ and $\beta$ integrin chains in cell-matrix interactions. Proceedings of the National Academy of Sciences, USA, 90: 1795-1799.

16. Nathanson SD, Haas GP, Bobrowski R, Lee $M$, Tilley $B$, Schultz $L$ \& Hetzel $F$ (1987). Regional lymph node and pulmonary metastases after local hyperthermia of melanomas in C57BL/6 mice. International Journal of Radiation Oncology, Biology, Physics, 13: 243-249.

17. Blood CH \& Zetter BR (1990). Tumor interactions with the vasculature: angiogenesis and tumor metastasis. Biochimica et Biophysica Acta, 1032: 89-118. 